\title{
The Central Role of the State in the Governance of Sport and the Olympic Movement in Tunisia, from 1956 to the Present Day
}

\section{Maha Zaoui \& Emmanuel Bayle}

To cite this article: Maha Zaoui \& Emmanuel Bayle (2018): The Central Role of the State in the Governance of Sport and the Olympic Movement in Tunisia, from 1956 to the Present Day, The International Journal of the History of Sport, DOI: 10.1080/09523367.2018.1463992

To link to this article: https://doi.org/10.1080/09523367.2018.1463992

曲 Published online: 12 Jun 2018.

Submit your article to this journal $\pi$

Q View related articles $\sqsubset$

View Crossmark data $\complement \nearrow$ 


\title{
The Central Role of the State in the Governance of Sport and the Olympic Movement in Tunisia, from 1956 to the Present Day
}

\author{
Maha Zaoui ${ }^{\mathrm{a}, \mathrm{b}}$ and Emmanuel Bayle ${ }^{\mathrm{c}}$

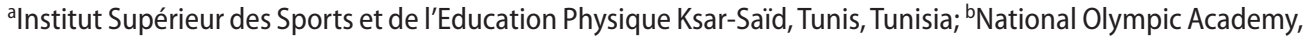 \\ Tunis, Tunisia; 'Lausanne University, Lausanne, Switzerland
}

\begin{abstract}
This paper examines the relationship between sport and the Tunisian state, focusing on the issues of governance and regulation. Identified are three periods: from independence to the coup d'état (20 March 1956-7 November 1987), where sport was a component of national identity; Ben Ali's regime taking control of the Olympic Movement, 1987-2011; and Post-2011, which witnessed attempts to achieve democracy. Descriptions of the situation in each of the three periods are followed by analyses of sports policies (objectives, resources, and results), legislation, turning points, and tensions.
\end{abstract}

\section{KEYWORDS}

Tunisia; national sport model; governance; regulation; sport and state relationship

Tunisia can be thought of as a 'promontory' between its neighbours around the Mediterranean and the Sahara Desert, a meeting point of influences from the Middle East, Africa, and the Mediterranean. The country was absorbed into the French Empire in 1881 following a major financial crisis and did not achieve internal autonomy until 1954. It was finally granted full independence in $1956 .{ }^{1}$ Tunisia's history since independence can be divided into three periods: the Bourguiba years (1956-1987), the Ben Ali years (1987-2011), and the 'transition' set in motion by the Tunisian revolution, which helped trigger the so-called 'Arab Spring' of 2011 by deposing Ben Ali's dictatorial regime and making way for a fledgling democracy. However, these 60 years of independent government have failed to solve Tunisia's economic, demographic, and social problems, and the country can still be characterized as 'underdeveloped.' As in many other independent nation states in the Arab world and Africa, all of Tunisia's post-independence leaders have been aware of sport's value as a component of national identity, ${ }^{3}$ with the result that politics has played a major role in shaping sport. ${ }^{4}$

In its determination to create a modern society, Tunisia's first post-independence government immediately began defining the country's geopolitical, cultural, and sporting position. ${ }^{5}$ President Habib Bourguiba quickly realized that sport was an excellent vehicle for consolidating and legitimizing the young nation state, thanks to its power in building national unity and obtaining international recognition: 'We need to be present at sports competitions, whether Arab, Mediterranean or worldwide ... The prestige provided by 
sporting exploits is undeniable. It rains down on the entire nation'. ${ }^{6}$ Bourguiba wanted Tunisia to become a bridge between East and West. As Ayari noted, 'compared with the rest of the Maghreb, Tunisia's political orientation can be considered progressive. Polygamy was abolished via a Personal Status Code and divorce became legal in 1956. ${ }^{\prime}$

However, in November 1987, Bourguiba was deposed by General Ben Ali, a former intelligence specialist and interior minister who Bourguiba had appointed prime minister just a month earlier. Ben Ali justified his coup on the basis of Bourguiba's increasingly erratic behaviour, which gave him an excuse to force the former president to step down 'for medical reasons.' ${ }^{8}$ The political system introduced by Ben Ali (1987-2011) was founded on three pillars: 'the Palace, the security apparatus and the president's family.' Indeed, 'between 1987 and 2011 this family circle acted like a predator on the Tunisian economy', ${ }^{10}$ and sport was increasingly used as an instrument of political propaganda. ${ }^{11}$ Ben Ali's regime was eventually toppled in the January 2011 revolution, and Tunisia has been transitioning towards democracy ever since. ${ }^{12}$

In Tunisia, as elsewhere, sport is much more than a codified confrontation between two or more players; it is also an inexhaustible source of symbolic and identity capital which sporting and/or political leaders readily draw upon. ${ }^{13}$ Because the state has been omnipresent in the history and organization of sport since 1956, sport organizations have no independence (appointment of executives by the state, finance provided almost entirely by the state, total political control, etc.). This is why the present paper focuses almost exclusively on the decisive role and weight of the state in the governance of Tunisian sport, in contrast to Western countries, where the relationship between the state and sport tends to be more 'balanced'.

Although several authors have investigated these issues in western countries, ${ }^{14}$ this is the first study to examine their specificities in a Maghrebi context. Henry and Lee (2004) identified three dimensions of the concept of governance: organizational, political, and systemic. ${ }^{15}$ The organizational dimension concerns the exercise of power within organizations, that is, the decision-making and steering mechanisms used to draw up and implement policies to improve an organization's performance and meet its objectives. The political dimension concerns the relationship between non-profit organizations and the political field, in both senses of the term. This dimension includes the way in which political institutions (states, European Union, etc.) try to influence, or even steer, the non-profit sector by introducing regulatory mechanisms covering organizations' finances and ethics, or by exerting other forms of political influence. Here, the issue of power is analyzed from an interorganizational, rather than an intra-organizational, perspective. The systemic dimension covers systems of interdependence, the regulation of inter-organizational relations, and the coordination of actions within complex systems. In the case of the sport system, the idea of complexity refers to the uncertainty of the environment, the number and diversity of stakeholders (public, non-profit, commercial), who often have different interests, and the numerous levels of coordination (from local to global). In terms of dynamics, the notion of systemic governance indicates the passage from a centralized, hierarchical, and vertical method (government) of regulating/coordinating actions to a horizontal approach centred round networks based on consensus/compromise and the sharing of power.

The present paper focuses on the political dimension of governance (and its consequences on the other two dimensions). It examines the complexity of the sport system and the influence of the state in managing and controlling this strategic sector. 
From a theoretical and methodological point of view, a number of researchers have tried to understand the relations between 'sport and the state' and the structure of national sport systems. Most notably, Houlihan suggested that the relations between 'sport and politics' can be categorized with respect to five components ${ }^{16}$ :

- The process of sport policy-making.

- The administrative framework for sport: the responsibilities of central or federal governments, state governments, and local authorities.

- The division of responsibility between different levels of government.

- How policy-making has addressed the topical problems of drug abuse by athletes.

- The provision of sport and physical education in schools.

This conceptual framework is mostly used to examine power relations and the way in which the sport system is steered.

One of the most comprehensive reviews of different national sport system models was provided by Camy et al. as part of the VOCASPORT report commissioned by the European Union (2004). ${ }^{17}$ Henry (2009) subsequently built on this initial research in order to more precisely define the different national sport system models and their consequences. ${ }^{18}$

This framework takes into account four parameters: the first is the role of public authorities, specifically the state, as represented by the Ministry responsible for sport; the second parameter relates to the level of coordination of, or engagement by, the various actors involved in the sport system. This can take the form of a legal framework or simply of a de facto prescription of the roles to be played by various actors; the third factor relates to the respective roles of the voluntary, public, and private sectors in the delivery of sporting provision; the fourth parameter relates to the adaptability of the system to changes in demand.

These four parameters give rise to four types of configuration:

- The 'bureaucratic configuration': This is characterized by the very active role that the public authorities take in regulating the system. There is almost always a legislative framework specific to the field (law on sport). It is a system characterized by rules from a public authority which, with its political/democratic legitimacy, does not necessarily negotiate to any great extent with other players. The voluntary sports movement acts by delegation, social partners are often non-existent, and users/consumers and private entrepreneurs have little impact on the implementation of sports policy.

- The 'entrepreneurial configuration': This is characterized by a high level of involvement of market forces.

- The 'missionary configuration': This incorporates those states for which the voluntary sector acts with delegated powers.

- The 'social configuration': This is characterized by the presence of social partners within a multifaceted system.

The absence of market forces rules out the entrepreneurial configuration and, even though there is some voluntary sector involvement in Tunisian sport, the dominance of the public system rules out the missionary configuration. Finally, the historical absence of social partners rules out the social configuration. Hence, the configuration which most closely corresponds to the situation in Tunisia is the bureaucratic configuration, albeit with a 
number of particularities relating to the way power is exercised and the cultural specificities of North African countries.

The present paper puts forward the thesis that the sport systems in North African countries are subject to a specifically 'authoritarian' form of governance that reflects their cultures of autocratic and despotic political leadership. This form of leadership has directly influenced the largely authoritarian way in which sport is organized and controlled. The commercial sports sector (fitness) is almost non-existent, there is little social dialogue, and, even more so than in most other countries, power is centralized at a national level, with very little delegation to local or regional authorities. Thus, Tunisian sport is run according to an interventionist model, ${ }^{19}$ in which sport is considered a public service and the sport movement is controlled by the state via national legislation laid down in the Acts of $1994^{20}$ and $1995 .^{21}$ Each government chooses the name they wish to give to the body responsible for overseeing sport, which may be a 'ministry, department, commission or agency, depending on the country.' ${ }^{22}$ In Tunisia, successive governments, depending on their political orientation, have chosen different names for this body.

Given that Camy et al. focused uniquely on democratic European countries, the objective of the present research was to examine the situation in a very different political context by conducting an historical analysis of the sport system in a North African nation.

The study was based on the four parameters identified by Camy et al. in $2004,{ }^{23}$ adapting them to the specificities of the Tunisian sport system, as follows:

- The role of the public authorities, especially the Minister for Education and the Minister for Youth and Sport.

- The degree of coordination, partnership, and discussion between the different stakeholders in the sport system, most notably the national Olympic committee, sports federations, and the regional authorities. The promotion of elite sport, on national, regional, and local levels, is mostly the remit of the federations. The Olympic committee is involved in preparing athletes who have qualified for the Olympic Games. The local and regional authorities are involved in encouraging participation in sport and exercise. The private sport system tends to be fully independent, working with hotels and the tourism sector.

- The role of sports associations, that is, the Olympic committee and the federations. A particularity of this part of this sport system is that up until 2011 one-third of its members were appointed (more or less openly) by the state and the president. The analysis of the part of the system examined legal and political aspects, as well as strategies of influence and control.

- Adaptability of the system. This is the ability of the system to respond to the demands of the market, taking into account the frequent use of sport by political leaders to further their own interests. Consequently, public opinion and the requirements of stakeholders are rarely taken into account in countries with authoritarian governments.

Consequently, the analysis of the relations between the state and the sport movement focused on the first three of these parameters and on elite sport (resources provided, exploitation of results, balance of power between executives, etc.), sports events (especially international events held in Tunisia), and leisure sport (changes in the types of participants and club members). Special attention was also paid to the place of women in sport 
(participants and executives), as this is an area in which Tunisia had taken a lead compared with other developing nations.

Data were collected in the following manner. Initially, the authors:

- Extracted quantitative data from the annual reports published by the Ministry for Youth and Sport (we were able to go back to 1995).

- Examined relevant legislation via Tunisia's online archive of national legislation. In fact, the current legal framework governing sport in Tunisia is mostly provided by two pieces of legislation, namely the Framework Act, no. 95-11 of 6 February 1995, relating to sport bodies, and Act no. 94-104 of 3 August 1994, on the organization and development of physical education and sports activities.

- Consulted two key works on the history of Tunisian sport. Both of these works are sports sociology doctoral theses that were defended in France and which cover the relations between the state and sport in Tunisia. They are 'Tunisian Sport in a Context of Development: A Systematic Approach Followed By a Dialectical Analysis', defended by Taoufik Haouet in 1981, and 'Archeology of a Political Discourse, Sport and National Construction in Tunisia (1956-1985)', defended by Borhane Erraïs in 1992.

- Collated information from the work of the Tunisian historian Driss Abbassi, who has published extensively on contemporary identity construction phenomena.

As a second stage, five semi-structured interviews with officials from the Tunisian Ministry of Youth and Sport (MJS), Tunisia's national Olympic committee (CNOT), and Tunisian sport federations were carried out as follows:

- Slim Chiboub: Ben Ali's son-in-law, president of the 'Espérance Sportive de Tunis' sports club from 1989 to 2004 and president of the CNOT from 2009 to 2011.

- Mahmoud Hammemi: General Secretary of the CNOT since 2011, general secretary of the Union of North African Football Federations since 2011, judge at the Court of Arbitration for Sport since 2009.

- Adel Zeramdini: Director of legal affairs at the MJS from 2005 to 2011, director of Shared Services from 2011 to 2012, and private secretary to the Minister of Youth and Sport from 2012 to 2014.

- Chokri Hamda: General secretary of the Observatory of Youth from 2009 to 2012, litigation department from 2012 to 2014, general secretary of the Higher Institute for Sport and Physical Education from 2014 to 2015, and director of legal affairs at the MJS since 2015.

- Maher Snoussi: Lawyer at the supreme court of appeal, member of the African Football Confederation's legal affairs committee, vice-president of the Tunisian Football Federation from 2012 to 2016.

These interviews covered the following themes:

- Changes in the relationship between the state and the sport and Olympic movements from independence to the present (1956-1987, 1987-2011, 2011-2016).

- Important legislation.

- Political intervention and the nature of sport policies (elite sport, sport for all, women's sport, sports events).

- Public finance (direct and indirect). 
- Sociological aspects (types of sport, participants, clubs, executives).

- Political interference and its objectives.

- Dysfunctions in terms of governance and opinion on changes to the electoral system.

We used the above-described theoretical and methodological framework to examine the evolution of the bureaucratic configuration in Tunisia and to determine whether the political, cultural, economic, and sporting contexts in Tunisia have produced any specific particularities. We then looked at how the three parameters considered in our analysis evolved during the most recent three stages of Tunisia's history (from 1956 to 1987, from 1987 to 2011, post-2011).

\section{From Independence to the Coup D'état (20 March 1956-7 November 1987): Sport as a Component of National Identity}

It is impossible to understand Tunisia's attempts to develop sport and physical education during the first 30 years of the country's post-colonial history without considering the political importance of sport in nation-building and obtaining international recognition. For President Bourguiba, sport was a valuable weapon in the fight against cultural and economic underdevelopment, as well as a way of raising Tunisia's profile on the world stage. Initial efforts to promote and cultivate sport were aided by a number of favourable circumstances. For example, the consequences of the country's colonial past, most notably the spread of the British sporting model among intellectual circles and a long period of political and diplomatic stability, allowed the new nation to set up numerous facilities for young people. In addition, the emancipation of women led to profound changes that affected all areas of society: polygamy was banned, divorce was made legal, and marriage was made subject to the consent of both parties. ${ }^{24}$ Numerous other rights obtained by Tunisian women at this time included the right to vote, granted in 1957. Sports policy during Bourguiba's 30-year presidency can be divided into three distinct periods.

\section{Using Sport to Help Build the New Nation State (1956-1966)}

During the colonial period, sport became 'an instrument in the struggle for independence' through the emergence of 'indigenous sports associations to rival those of the colonizer'. ${ }^{25}$ Once independence had been obtained, sport became a weapon in the fight against underdevelopment. ${ }^{26}$ President Bourguiba’s desire to make sport an important part of society and to create a nation that appreciated and played sports reflected his belief that no general education could be complete if it did not include a sporting dimension and that sport was the best way to shape the nation's youth and instil a love of country.

As a first step in achieving this objective, on 21 June 1956 he created a Ministry of Youth and Sport with its own Secretary of State. The new ministry, which replaced the Ministry of Education's Youth and Sport Department, ensured a degree of autonomy for sports policy and showed the government's commitment to the country's youth. ${ }^{27}$ The state, ${ }^{28}$ which 'would play a decisive role in and complete the construction of the nation', ${ }^{29}$ further consolidated its control over sport by progressively creating other bodies and introducing new legislation to reform Tunisia's sport movement. For example, the Sports Committee became the Tunisian Sports Committee on 28 June 1956; the country's scouting bodies were 
merged to form the Tunisian Scouts Association on 1 July 1956; the National Institute of Sport was founded on 1 January 1957; the Tunisian Olympic Committee was set up on 27 May 1957; the Youth and Sports Department was integrated into the Ministry of Education in May 1958; and a Youth and Sports Directorate was created within the President's Office on 8 January 1959. In addition, decrees were published to establish a 'National Olympic Day' (8 May 1959), to control the activities of sports associations, federations, and groups (8 November 1959), to regulate sports betting and create a 'National Sports Fund' (27 January 1960), and to cover the 'regime of civil sports' (9 February 1960). Finally, a Higher Committee for Youth was set up on 24 February 1961, and a 'Sports Instructor Training School' was inaugurated in October 1961.

Bourguiba used education and sport as the basis for a number of major initiatives to try and transform mentalities in independent Tunisia. Moreover, his speeches regularly referred to the role of the state and the importance of controlling the sports sector. ${ }^{30}$

Efforts to increase the importance of physical activity and sport within society also included the Tunisian school system, which underwent a series of major reforms. For example, the time allocated to physical education was increased from two hours in 1956 to three hours in 1966, with Friday afternoons being set aside for official school competitions. Particularly gifted youngsters attended special sports schools that dedicated even more time to sport. Bourguiba's sensitivity to the West's opinion of Tunisia ensured that women and girls were also included in efforts to promote sport. In addition, encouraging girls to take up sport at school facilitated the development of leisure sport and elite sport and, within just a few years, Tunisian women were achieving excellent results in Arab, African, and Mediterranean sports competitions. ${ }^{31}$

These decisions show that Tunisia was adopting a 'western model', especially with respect to physical education, where school syllabuses were greatly inspired by the approach used in France. However, in contrast to the situation in France, Tunisia did not create the conditions in which sport could grow, especially with respect to sports facilities, school and university sport, competitive sport, and leisure sport. ${ }^{32}$

As he noted on 30 September 1960, Bourguiba considered sport to be a way of 'improving the physical, intellectual and moral condition of an individual and of the people..33 Consequently, the MJS drew up a policy to encourage people of all social classes to take up sport and an action plan to help the elite sportspeople that would emerge from this wide sporting base. The only way these objectives could be achieved was through state intervention. ${ }^{34}$ The Minister of Sport introduced standard statutes for sport federations and clubs, laying down rules for how they could be formed and run. To ensure all the different federations were fully integrated into Tunisian sport, and in order to set up a programme for preparing and helping elite sportspeople, highly qualified technical directors were appointed to federations. ${ }^{35}$ Furthermore, the MJS introduced three measures to help Tunisia's elite sportspeople move up to a higher level: it set up a national coaching school (four-year study programme), it drew up a new training programme for coaches, and it provided federations and clubs with highly qualified coaches who would encourage sport at all levels throughout Tunisia, pick and train regional teams, and orient and improve the existing framework. In addition, the MJS covered the cost of paying coaches, provided substantial subsidies in the form of financial and material resources, and allowed clubs to obtain sponsorship from companies. 
Hence, the government's actions during this period focused both on building reliable administrative and legislative structures and on sports policy, training executives, setting up structures for elite sport, and sending envoys to international sporting bodies to ensure the national team was invited to international sports events and to obtain positions within these bodies. Tunisia first took part in international competitions in 1957, at the Festival of Sports and at the third Pan-Arab Games in Beirut, and in 1960 the country's soccer team competed in the first edition of the Africa Cup of Nations in Accra. In the light of the honourable results achieved by Tunisian athletes at these events, the government decided to send teams to more prestigious events such as the Mediterranean Games in Beirut (1959) and the World Military Boxing Championships in New Jersey (1961).

\section{An Important Tool for Increasing the Young Nation's International Profile and Reputation (1967-1977)}

For Tunisia's government, sport was a precious ally in the fight against cultural and economic underdevelopment; it was the road that would facilitate Tunisia's entry into the international sphere. This 'political strategy' was crowned by the success of Tunisian athletes at international competitions in the 1960s (e.g. Mohammed Gammoudi won silver in the 10,000 metres at the 1964 Tokyo Olympics and gold in the 5,000 metres at the 1968 Mexico City Games). The government relied heavily on international sporting success and on the hosting of major sports events to raise the country's sporting and political profiles around the world. By hosting several 'second tier' international events, such as the World Military Cross-Country Championships in 1966 and the Maghrebi Boxing and Gymnastics Championships in 1968, the country was able to demonstrate its organizational abilities and show how it was progressing as a modern country open to the outside world. The sporting, spectator, and media successes of these events resulted in Tunisia being chosen to host the 1967 Mediterranean Games. This event, held in the newly built National Olympic Complex, the 'pride of an entire nation', and involving 12 countries, was the culmination of a phase notable for its 'Exemplary Tunisia' plan. ${ }^{36}$ It was also the first edition of the event to include female athletes. Bouabdallah Beya, a great sporting all-rounder, ${ }^{37}$ and a pioneer of women's sport in Tunisia, provided her country with its first women's medals. ${ }^{38}$ At the end of the Games, Tunisia was ranked sixth in the medals table with five gold, nine silver, and 11 bronze medals. Morocco was eighth with five medals, followed by Algeria with three medals. The exploits of Tunisia's women athletes continued throughout the 1970s, culminating with victory in the 1976 African Women's Handball Championships in Algiers.

Bourguiba's objective in hosting international competitions, especially the Mediterranean Games, was to show off Tunisia as an enterprising, dynamic, and emancipated nation. The country's emergence into the world of international sport was confirmed by the creation of the Tunisian National Olympic Committee (CNOT), whose members were drawn from the national sport federations that had been set up by the government to replace the preindependence system of sports leagues. The CNOT was founded on 27 May 1957, when the Tunisian Athletics Federation invited representatives of the country's 17 sport federations to a meeting at which they elected the committee's first Executive Board. On 23 September 1957, in Sofia, Bulgaria, the International Olympic Committee (IOC) Session officially recognized the new NOC, allowing Tunisia to participate in competitions organized under the IOC banner. However, Tunisia's quest for international recognition was more ambitious 
than merely competing in major competitions; it also wanted to have a voice within international bodies. Tunisia's first international sports administrator and spokesperson was Mohamed Mzali, who Bourguiba, once again exerting his power over the sport movement, ${ }^{39}$ had had 'elected' to the presidency of the CNOT (1962-1986). Mzali now held the three most powerful jobs in Tunisian sport - the politico-administrative post of Director of Sports and two representational posts as president of the CNOT (1962-1986) and president (1962-1963) and then vice-president (1963-1967) of the Tunisian Football Federation. These positions allowed him to implement Bourguiba's sports policies within Tunisia and to promote these policies around the world. As president of the CNOT, Mzali had access to the highest echelons of international sports administration, becoming a member of the IOC in 1965, a member of the IOC's Executive Board in 1973, and then vice-president (1976-1980) and president of the International Committee of the Mediterranean Games (1979-1987). ${ }^{40}$ Tunisia's National Olympic Day, created in 1959 in order to instil the sporting spirit among the country's youth, was another element in this quest for Olympic recognition. ${ }^{41}$

However, this period was also marked by political instability at the head of Tunisian sport, with the MJS being led by seven different ministers, each with his own political agenda. For example, one minister, who was known for his authoritarian stance, used crowd trouble at a football match between Espérance Sportive de Tunis (EST) and Sportif de Sfax on 13 June 1971, as an excuse to dissolve the Tunisian Football Federation, the EST football club, and its fan club. Even though the large number of medals won by Tunisian athletes during this period gave the impression that Tunisian sport was in good health, it was subject to perpetual political interference from a directive and authoritarian government that attempted to exercise its control by appointing carefully selected people to the boards of sports associations and federations. ${ }^{42}$ In fact, because government policy focused so heavily on using prestige sport to serve its political interests, the overall situation of Tunisian sport at this time was not as 'educational' as the government tried to make out. For example, at the end of 1977, Tunisia's sport federations had just 46,476 registered athletes, that is, $0.77 \%$ of the country's population or $1.05 \%$ of under-35s. Most of these registered athletes (57\%) were in just five regions (Sousse, Nabeul, Monastir, Bizerte, and Kairouan), while none of Tunisia's other 10 regions had more than 1,700 registered athletes. ${ }^{43}$

In addition, financial support for sport was heavily concentrated in the capital region. For example, during the period 1962-1971, 4,460,000 dinars (1,980,500 euros), out of a total budget of 6,213,000 dinars (2,759,000 euros), were spent building the National Olympic Complex in Tunis for the 1967 Mediterranean Games, while only 1,753,000 dinars $(778,500$ euros) were allocated to the country's regions. To give some perspective, in 1977 Tunisia's per capita GDP was approximately 792 euros, compared with 6,860 euros in France. ${ }^{44}$ The end of the Bourguiba regime would herald the beginning of a new period in Tunisian sport.

\section{Sport as a Tool for Calming Social Unrest (1978-1987)}

The decade from 1978 to 1987 was a highly turbulent period for the Bourguiba government. On 26 January 1978, a major breakdown in the relationship between the state and the people led the Union Générale Tunisienne du Travail (UGTT) to call the first general strike since the country's independence. This strike triggered an uprising against Bourguiba's government in which thousands of demonstrators assaulted ministries and public buildings across the capital. A total of 51 people were killed. ${ }^{45}$ This social unrest coincided with a 
meeting of the IOC's Executive Board in Tunis, which Mohamed Mzali had hoped would show international sport's top executives a positive image of Tunisia and the young nation's achievements in the field of youth and sport. ${ }^{46}$ Nevertheless, Bourguiba's attempts to shield sport from the problems within Tunisian society and continue its development were given a huge boost by the Tunisian football team, which, for the first time in the country's history, qualified for the World Cup finals, due to take place later that year in Argentina. On hearing the news, the Tunisian people once again took to the streets, this time in a celebratory mood. Barely two months had passed since the riots, but the football team's exploit had given the entire country a huge boost and helped calm the people's anger.

However, the gulf between the regime and the nation continued to deepen and by 1979 the government realized it would have to do more to improve its legitimacy. One of its responses was to send the Minister for Youth and Sport on a tour of the country to highlight the government's efforts and successes in developing school sport, children's clubs, sportstudy classes, leisure sport, and sports infrastructure. Sport had become an important card in saving the state and demonstrating the government's efficacy.

Following this succession of social crises, and in order to achieve a new balance, Bourguiba made Mohamed Mzali, Tunisia's leading sports administrator, his new prime minister in 1980. However, decisions by the new government's Minister for Youth and Sport increased the exodus of Tunisian coaches to other Arab countries. ${ }^{47}$ The resulting lack of top-class coaches resulted in the national football team repeatedly failing to qualify for the World Cup Finals (until 1998) and Olympic Games (until 1988). ${ }^{48}$

By 1984 the country was once more in crisis, ${ }^{49}$ and, again, the Minister for Youth and Sport used sport to reduce tensions, referring in his speeches to the importance of preserving the sporting ethic from threats such as regionalism and fanaticism, and the need to cultivate patriotic feelings among all Tunisians, especially the young. Mzali, in his role as 'Olympic philosopher', invited Tunisian society to meditate on the values of Olympism and to adopt its ethic. His speeches during this period frequently referred to Olympism and he even set up a conference entitled 'The contribution of Olympism to international understanding and peace', held in July 1984.

\section{Ben Ali's Regime Takes Control of the Olympic Movement, 1987-2011}

The destitution of President Bourguiba on 7 November 1987 marked the end of the population's support for Tunisia's first president and of the first stage in the building of a nation state. ${ }^{50}$ The second phase brought new perspectives, new rules, new aims, and a new president who had to demonstrate his legitimacy.

The crisis afflicting Tunisia's economy in the early 1980s had resulted in the International Monetary Fund and World Bank pressurizing the government to reduce the state's role in the economy and introduce market-based mechanisms. As a result, Tunisia began a long process of liberalization that affected every aspect of expenditure. Government departments, including those responsible for sport, saw large cuts being made to their budgets. In addition, sport organizations, which had developed within a public and interventionist environment, had to adapt their governance and legislation to new international standards. Tunisia's second president, Zine el Abidine Ben Ali, made extensive use of sport to promote and legitimize his regime, but sport as a whole suffered from the regime's despotic management and narrow focus. In fact, between 1987 and 2011, Ben Ali's family circle ${ }^{51}$ 'acted like a predator on the 
Tunisian economy ... In order to control society, this bureaucratic-patrimonial complex used organizations, bodies and networks to keep a close watch on the population and adopt a clientilist approach to distributing material and symbolic resources. ${ }^{52}$

\section{Using International Events to Demonstrate the Regime's Legitimacy}

After seizing power, Ben Ali and his allies reassured the opposition and the Tunisian people of their good intentions by taking a series of liberal and constitutional measures (release of political prisoners, abolition of lifetime presidents, etc.). At the same time, they made their first moves to extend their control over the political scene and consolidate their power (removal of executives who vaunted the virtues of democracy, reminders to journalists and editors that certain lines should not be crossed, etc.). Tunisia was turning a new political and ideological corner, although sport continued to be seen as an essential vehicle for building feelings of belonging and identification and sport was extensively used to promote the country's new multi-layered identity (Mediterranean, African, Maghrebi, and Muslim). One of the ways the new government did this was by staging major sports events, which could be invested with great political, financial, and symbolic meaning. This policy's success in legitimizing the regime and raising Tunisia's international profile is reflected in the large number of events the country hosted during the 24 years of Ben Ali's reign, including the Africa Cup of Nations in 1994 and 2004, the 2001 Mediterranean Games, the 2005 World Handball Championships, and numerous African, Maghrebi, and Arab Championships in sports such as athletics, judo, and swimming. ${ }^{53}$

The Tunisian authorities used the opening ceremonies for international sports events to demonstrate Tunisia's historic roots (Carthaginian, African and Mediterranean) and to highlight the figure 7, which symbolized the new political regime that emerged from the events of 7 November 1987, and which was displayed everywhere (in the names of stadiums, on advertising posters, etc.). Ben Ali used these events to promote his efforts to help young people and develop sport. For example, two weeks after launching the 2001 Mediterranean Games, the president invited everyone involved to the Mediterranean Games Village in order to thank them for their hard work and, most importantly, to announce rewards for gold, silver, and bronze medal winners of 100,000 dinars (44,500 euros), 75,000 dinars (33,500 euros), and 50,000 dinars (22,300 euros), respectively (Tunisia's per capita GDP in 2001 was approximately 2,087 euros, compared with 20,565 euros in France). ${ }^{54}$ This announcement was praised by the entire Tunisian sporting community, which won a total of 59 medals at the Games (19 gold, 13 silver and 27 bronze), placing it 6th out of the 23 participating nations.

Hosting major sports events also helped raise Tunisia's international profile. The Tunisian authorities wanted to export an image of a modern nation state that was open to the outside world. This modernity could be seen both in media coverage of the events, which made extensive use of new technologies, and in the acclaim given to women athletes. Hence, as well as boasting of having the only capital city to have hosted the Mediterranean Games on two occasions and of staging the first edition of the Games to feature 23 nations and 23 sports, Tunisia used the 2001 Mediterranean Games to show itself as a truly emancipated country. Tunisia's proud history of encouraging participation by female athletes had begun at the 1967 Mediterranean Games, the first edition of the event to include women from the Maghreb. ${ }^{55}$ The 2001 edition was used to build on this legacy by adding women's events in three new sports (rowing, wrestling, and weightlifting). This aim was helped by the dazzling 
performance of Tunisia's women's team, which won 18 medals (six gold, one silver, and 11 bronze), a result that was presented as proof of the success of the Tunisian Government's policies in promoting sexual equality and in improving the lot of women in general and of sportswomen in particular. ${ }^{56}$

In the world of football, Tunisia's performances in the Africa Cup of Nations had varied from a humiliating first-round exit at home in 1994 (eliminated by Mali) to reaching the final on two occasions, in 1965 (beaten by Ghana, at home) and in 1996 (beaten by the hosts in South Africa). The Tunisian team finally made history by winning the tournament in 2004, when they delighted the home crowd by beating Morocco in the final. This sporting success was quickly turned into a political victory and a vindication of Ben Ali, the 'Man of November 7'. To the immense satisfaction of the Tunisian authorities, the positive image it gave of the country was relayed by a number of political and sporting figures around the world. ${ }^{57}$ In fact, international events were part of the government's electoral strategy, supported by mainstream and political clientilism in the provision of sporting subsidies, which it used to increase its electoral base and political power. ${ }^{58}$ This, combined with a major media effort, is why 'the performances of Tunisian athletes in 2001 and the national football team's victory in the 2004 Africa Cup of Nations provided Ben Ali with the glory and prestige Bourguiba (1956-1987) never enjoyed'. ${ }^{59}$

\section{Between Despotism and Prejudice}

It is important to note that Ben Ali implemented his policies through the bureaucracy set up by Bourguiba. Although neither regime was democratic, ${ }^{60}$ the two systems of government were very different. Ben Ali's government was characterized by secrecy and the establishment of a police state which tried to control every aspect of Tunisian life, including sport.

\section{The State's Stranglehold on Sport}

According to Chouikha and Gobe, 'Up until the beginning of the 2000s, Ben Ali's regime introduced a series of institutional reforms in order to establish a tightly controlled system that would ensure the continuation of the authoritarian regime ... Their aim was to reward party leaders and organizations which had shown allegiance to the government. ${ }^{61}$ The results of this for ordinary Tunisians was a decline in government services and an all-pervasive monitoring of every aspect of daily life by the police and security services. ${ }^{62}$ Regime loyalists controlled every important organization in the country, including its sport organizations, which were supposed to be neutral, democratic, and non-governmental, but which, in reality, were run by executives chosen by the political police and approved by the ruling party. ${ }^{63}$ The result was inequality, favouritism, fraud, and corruption. ${ }^{64}$

These practices intensified during the final years of the Ben Ali regime due to marginalizing and oppressive governance by Tunisian sport's two top administrators. The first, Abdelhamid Slama, was Ben Ali's advisor on culture, youth, and sport (as well as president of the CNOT from 2004 to 2009). He was appointed Minister of Sport at the beginning of January 2011, just a few days before the revolution. The second, Slim Chiboub, was Ben Ali's son-in-law and Abdelhamid Slama's successor as president of the CNOT (2009-2011). Chiboub was also president of a major sports club and an influential figure in the world of sport. ${ }^{65}$ 
During the early years of Ben Ali's regime, the CNOT had continued to enjoy a degree of independence and an internationalist stance. However, the regime gradually tightened its control over the CNOT, first by imposing new statutes, drawn up by Slama in 1991 in his role as commissioner general for sport, and then through the appointment of Ben Ali's son-in-law as president in 2009.

\section{Questionable Public Finances}

In general, 'sport owes its rise to federal power'. ${ }^{66}$ Nevertheless, federal power is currently facing new challenges created by new social, economic, and political realities, both nationally and internationally. Moreover, although the public authorities and private investors provide both commitment and financial support, they are also competitors for control over the sector. In fact, when sport federations are made responsible for running a public service, the state can control management procedures and the way in which federations carry out their missions by imposing a strict legislative and regulatory framework.

The largest source of public finance for Tunisian sport during the Ben Ali period was the MJS, which provided an estimated 21 million dinars (approximately 9 million euros) in subsidies. Extra finance was provided by local authority subsidies ( 9 million dinars/4 million euros in 2009, excluding sports facility maintenance), the National Fund for Youth and Sport (FNPJS, 10 million dinars/4.5 million euros for the 2008-2009 season), and other public sources, such as broadcasting rights from the state television company FTF and donations from publicly owned companies.

The FNPJS, now known as Promosport, was set up by the government in 1979 to help sports clubs cover their operating costs and provide a safety net against any future economic problems. ${ }^{67}$ Supposedly financed uniquely by a lottery based on the final classification of non-amateur football leagues, its receipts for 2010 are estimated to have been 35 million dinars (15.6 million euros). Receipts were divided among the various parties as follows: $50 \%$ to the MJS to provide subsidies for clubs and sports associations (20\% of which were paid directly to the 'treasury of the presidential palace'), $40 \%$ to the lottery winners, and $10 \%$ to the company responsible for running the lottery. ${ }^{68}$ Nevertheless, the distribution of subsidies during the Ben Ali years was highly contestable.

Because subsidies were based on membership numbers, clubs and associations would sometimes swell their ranks by recruiting 'ghost' members, most of whom would never be seen, in order to get the largest possible subsidy. In addition, clubs with well-placed contacts would use them to obtain preferential treatment, so the allocation of subsidies was rarely equitable.

Another problem was the lack of resources available for individual and women's sports due to the decision to specialize in certain 'targeted' sports, chosen on the basis of previous results. Targeted sports received privileges that were not accorded to other sports, including a substantial budget, sufficient training camps to meet the needs of elite athletes, and topquality coaching. In contrast, non-targeted sports did not receive enough resources to implement effective development plans and therefore continued to be losers in the system.

For many years, sports associations relied heavily on state subsidies to meet their everincreasing financial needs, as finance was kept exclusively public in order to ensure sport remained open to all and to nurture Tunisia's image. The government also wanted to 
maintain its control over sport and create a breeding ground for elite athletes capable of competing at the highest national and international levels.

In such an environment, and with these sports policies, the federations, which rely on volunteers, began considering how they could change the way they were run in order to adapt to these new socioeconomic realities.

\section{Inconsistencies in the Regime's Sports Policy}

A number of criteria can be used to differentiate between a true sport policy and a group of measures implemented sporadically and with no overall cohesion. ${ }^{69}$ According to Mény and Thoenig (1989), 'analysis of a public policy should reveal: (1) a general framework for action; (2) an explicit definition of the goals or objectives to be met as a function of standards and values; (3) a collection of concrete measures that form the substance and foundation of the policy; (4) the people at whom the policy is aimed; (5) a decision-making mechanism for allocating resources and/or drawing up regulatory measures. ${ }^{70}$ Failure to include all these elements in a sport policy can lead to failings, disparities, and discrimination.

The unfairness of the government's policy affected all areas of sport. A large geographical disparity arose in the numbers of people doing sport, as more than $60 \%$ of regular participants, both boys and girls, and almost $46 \%$ of sports associations (between 2008 and 2009) were concentrated in Tunisia's eight coastal governorates (the country is divided into 24 governorates). Low participation rates in some regions were the result of the school sport system, as some sports declined in popularity because they were no longer done at school and because they received little support from the state. For example, between 1992 and 2002, there were substantial falls in the number of school athletes in non-targeted sports such as swimming (from 1028 to 383), gymnastics (from 1337 to 897), and table tennis (from 328 to just 39), with a corresponding rise in numbers competing in targeted sports such as judo (from 1058 to 2374). In fact, Tunisia's performance-centred sporting model was unsuited to the country's economic and constitutional characteristics and therefore bound to fail in terms of developing sport as a whole. Furthermore, the focus on prestige, the absence of suitable structures for other aspects of sport, and the lack of human and financial resources meant that the national sport system continued to be excessively tilted in favour of elite sport at the expense of other areas of sport, such as sport for health and leisure sport.

\section{Women's Sport as Proof of Success}

At this time, women's sport was constantly presented as tangible proof of women's emancipation in Tunisia and, most importantly, of the support given to women and women's sport, most notably by the president's wife, Leila Ben Ali. As a result, the number of registered women players increased from 10,978 to 27,449 between 2000 and 2007, although the provision of subsidies to organizations with large numbers of women members means that these figures, too, may have been falsified. Tunisia's 775 elite sportswomen were responsible for $42 \%$ of the medals won by Tunisian athletes in major international competitions, including three world championships. However, sportswomen accounted for only $15 \%$ of the country's registered athletes, as sports clubs never had more than 12,000 female athletes, 4,000 of who played one of four team sports. The remaining 8,000 female athletes were spread across another 20 sports, which means that, on average, each sport 
and each federation had just 400 female members covering all age groups. At the school and university levels, there were 33,000 registered sportswomen $(0.2 \%$ of women and girls in education), compared with 73,000 sportsmen; hence, women accounted for only $30 \%$ of student sportspeople. ${ }^{71}$

\section{Post-2011: Attempts to Achieve Democracy}

The 'revolution' of 14 January 2011 affected every area of Tunisian life, including sport. Ben Ali's despotic regime had dominated sport for 23 years by ensuring people close to the regime controlled every important sport organization. To remedy this situation, on 14 July 2011, a ministerial decree was published (Decree-Act no. 2011-66 modifying Organic Law no. 95-11 of 6 February 1995), ${ }^{72}$ requiring all Tunisia's national sport federations to elect new executive boards by calling special elective general assemblies and allowing them to replace the standard statutes imposed by the previous government with new statutes of their own devising. This decision was welcomed across Tunisia's sporting system, although the removal of the government's 'direct' influence required federations to make profound changes to their governance, especially its political dimension.

However, in order to maintain a degree of control over the federations, the Minister for Sport retained article 21 of Organic Law no. 95-11 of 6 February 1995, which states:

The minister responsible for sport may, in the case of management failures or mismanagement, end the activities of one, several or all the members of an executive board via a ministerial order explaining the reasons underlying the decision. If the activities of at least half the members of an executive board are ended, the minister for sport may appoint an interim board whose responsibilities will include calling a general meeting within a period not exceeding three months from the date of the order.

Since the revolution, this article has been used to dissolve 10 sport federations, ${ }^{73}$ for reasons including failure to hold an elective general assembly as required by Decree-Law no. 66/2011, resignation of more than a third of the executive board's members, dissolution of the executive board following a decision by the National Sports Arbitration Committee, and administrative and financial mismanagement. However, in two cases, appeals by the national federation to its international federation have been upheld, thereby annulling the dissolution order. This was the case for the Tunisian Athletics Federation, whose appeal was heard by the International Association of Athletics Federations, and the Tunisian Boxing Federation, which appealed to the International Boxing Association.

Today, the Tunisian sports movement is managed by two groups of stakeholders who jointly organize, manage, and promote sport. One group consists of public authorities, represented by the state, the relevant government ministry, which is subject to great political instability, ${ }^{74}$ and its local representatives (a regional Youth and Sport Commission in each of Tunisia's 24 governorates). The other group consists of private entities, represented by the sport movement (1,400 associations, including 87 women's associations and 47 federations) and the Olympic movement, represented by the CNOT. The budget allocated to the MJS for 2016 was 555,904,000 dinars (225,500,000 euros), compared with 501,722,000 dinars (204,000,000 euros) for 2015.

As 2016 was an Olympic year, in addition to the 23-million-dinar (9,350,000-euro) budget allocated by the MJS to elite sport, the government provided a further 2,282,000 dinars (928,000 euros). This budget was managed by the ad hoc commission set up to 
prepare for the Olympic Games, which consisted of representatives from the MJS and the CNOT. At the Rio Olympics, Tunisia won three bronze medals, two for the women's team (Ines Boubakri in fencing and Maroua el Amri in wrestling) and one for the men's team (Oussama Oueslati in taekwondo).

\section{Conclusion}

Since independence, the state has been intimately involved in organizing, running, and financing sport. Consequently, the responsibilities of the different stakeholders within the sport system have been diluted.

The analysis shows that Tunisia's post-independence sport system has been run according to an authoritarian, bureaucratic, government-controlled model, but with important differences between the three main periods in the country's recent history. The initial version of the model, instigated by Bourguiba, was intended to help build national identity and to ensure a place for Tunisia on the world's sporting stage. Under Ben Ali, the model evolved into a 'clientilist system' designed to protect the status quo and help the powers retain their control over all areas of public and commercial activity. Nevertheless, both periods were characterized by strict state supervision and even indoctrination of the stakeholders involved in sport. Since the revolution in 2011, the Tunisian sport system has become more 'fragmented' as attempts are made to move towards a more democratic model.

This authoritarian, bureaucratic model differs from the bureaucratic model defined by Henry ${ }^{75}$ in that it is built on interventionist sports legislation where the promotion and the development of sport are considered public services provided by the sports movement, controlled, to a greater or lesser extent, by the state. ${ }^{76}$ In Tunisia, government control is particularly strict, as sports federations must apply for government recognition (from the appropriate ministry), adopt standard statutes, and follow set operating procedures. Furthermore, state intervention has led to the sport system being dominated by people close to the government, a form of indoctrination and clanism. Finally, this model places much greater importance on trustworthiness and faithfulness to the regime, than on the processes and procedures described by Henry. ${ }^{77}$ Given the links between the Tunisian Government's tight control over sport and the country's political system and culture, we would expect the authoritarian, bureaucratic model to also occur in other North African countries with similar characteristics, but further research is needed to confirm this.

The deterioration in the structure and organization of Tunisian sport since the 2011 'revolution', due to recent governments not considering sport a central element in the new Tunisian state, has led some people to begin lamenting the passing of the previous regime. The difficulties and dysfunctions described in this paper raise the question of how the state's current involvement in sport can be adapted to suit the new political context.

\section{Notes}

1. M.B. Ayari, 'Quelques éléments d'analyse historique' ['A Preliminary Historical Analysis'], in B. Ayari et al. (eds), Tunisie: Une révolution démocratique et sociale [Tunisia: A Democratic and Social Revolution], Documents d'Etude de la Formation Léon Lesoil, no. 5 (January 2011), 44.

2. See Jacques Soppelsa's geopolitical blog: 'La Tunisie contemporaine: esquisse d'analyse géopolitique’ [Contemporary Tunisia: A Geopolitical Analysis] (12 September 2011). 
3. Driss Abbassi, 'Sport et usages politiques du passé dans la Tunisie des débuts du XXIe siècle' ['Sport and Past Political Practices in early 21st-Century Tunisia'], Politique et Sociétés 26, nos 2-3 (2007), 125-42.

4. Y. Fatès, Sport et Tiers-Monde [Sport and the Third World] (Paris: PUF, 1994).

5. L. Chouikha and E. Gobe, Histoire de la Tunisie depuis l'indépendance ['History of Tunisia since Independence'] (Paris: La Découverte 'Repères', 2015).

6. Habib Bourguiba, 'Le rôle du sport dans la bataille contre le sous développement', Discours, t. VIII, 1960-1961 (Tunis: Secrétariat d'État àl'information, 1976), 102-3, cited in Abbassi, 'Sport et usages politiques du passé dans la Tunisie des débuts du XXIe siècle' ['Sport and Past Political Practices in Early 21st-Century Tunisia'].

7. Ayari, 'Quelques éléments d'analyse historique' ['A Preliminary Historical Analysis'], 2.

8. A. Saal, 'Chronologie des faits internationaux d’ordre juridique (année 1987)' ['Chronology of International Legal Events (1987)'], in Annuaire français de droit international [French directory of international law], 33 (1987), 1031-42.

9. Chouikha and Gobe, Histoire de la Tunisie depuis l'indépendance [History of Tunisia since independence], 55 .

10. Ibid., 57.

11. Borhane Erraïs, 'Archéologie d'un discours politique, sport et construction nationale : l'exemple tunisien (1956-1985') ['Archeology of a Political Discourse and Nation Building: The Case of Tunisia (1956-1985)'] (PhD diss., Université Paris, 1992), 7.

12. A. Stepan, 'Tunisia's Transition and the Twin Tolerations', Journal of Democracy 23, no. 2 (2012), 89-203.

13. F. Moroy, 'Football et politique à Tunis' ['Football and Politics in Tunis'], Correspondances (Tunis, 2001), cited in Driss Abbassi, 'Sport, légitimation politique et construction identitaire dans la Tunisie des années 2000' ['Sport, Political Legitimization and Identity Building in Tunisia in First Decade of the 21st Century'], L’Année du Maghreb III (2007), 409-26.

14. I.P. Henry and P.C. Lee, 'Governance and Ethics in Sport', in J. Beech and S. Chadwick (eds), The Business of Sport Management (Harlow: Pearson Education, 2004), 25-42; I.P. Henry, 'European Models of Sport: Governance, Organisational Change and Sport Policy in the EU', Hitotsubashi Journal of Arts \& Sciences 50 (2009), 41-52; Emmanual Bayle, 'Institutional Changes and Transformations in an Organizational Field: The Case of the Public/Private "Model" of French Sport, International Journal of Public Policy 1, nos 1/2 (2005), 185-211; and Barrie Houlihan, Sport, Policy, and Politics: A Comparative Analysis (London: Routledge, 1997).

15. Henry and Lee, 'Governance and Ethics in Sport'.

16. Houlihan, Sport, Policy, and Politics.

17. Camy et al. Vocasport. Improving Employment in the Field of Sport in Europe Through Vocational Training. Vocational Education and Training in the Field of Sport in the European Union. Stiation, Trends and Outlook (Lyon: Université Claude Bernard Lyon 1, 2004).

18. Henry, 'European Models of Sport'.

19. According to Chaker, in the interventionist model, the missions of key players within the sport movement are laid down by national legislation. This model ensures a certain amount of continuity in the policies carried out and the obligation to report what is achieved, as it is based on official, legal measures. In fact, 'interventionist legislation in the field of sport is also used to establish or maintain order in the national sports movement'. André-Noël Chaker, 'Bonne gouvernance dans le sport - Une étude européenne' ['Good Governance in Sport - A European Study'], Editions du Conseil de l'Europ (September 2004), 10.

20. Several articles within the Act of 3 August 1994, on the organization and development of physical education and sports activities (no. 94-104), refer to the 'STATE' and its relations with the sports movement. For example, under Article (3), 'the state defines policies relating to the organization of physical education and sports activities, is responsible for overseeing, monitoring and protecting them from violence, speculation, doping and all abuses that go against the principles of healthy emulation and the respect of moral and sporting values'. Article (4) 'The state and local authorities contribute to developing physical education and 
sports activities by providing moral, technical and financial support to sporting bodies in accordance with current legislation'. Article (38) 'The state is responsible for developing elite sport in conjunction with sporting bodies and public and private institutions. The quality of elite sport will be determined according to criteria set by the Minister for Sport, in the light of proposals made by the national commission for elite sport, whose composition and procedures will be defined by the Minister for Sport'.

21. Organic Law no. 95-11 of 6 February 1995, on sporting bodies (1). Under Article (9), 'The sport federation will provide a public service within the framework of the mission it is given by the Minister for Sport'. Article (14) stipulates that 'The sport federation is run by a federal committee. Two-thirds of the committee's members will be elected; the remaining third will be appointed by the Minister for Sport'.

22. Chaker, 'Bonne gouvernance dans le sport' ['Good Governance in Sport'], 12.

23. See note 17 above.

24. Borhane Erraïs and S. Erraïs, 'Le sport féminin à l'épreuve de l'intégrisme religieux' ['Women's sport in the face of religious fundamentalism'], in P. Arnaud and Thierry Terret (eds), Histoire du sport féminin, Tome 2, Sport masculin-sport féminin: éducation et société ['History of Women's Sport, Volume 2, Men's and Women's Sport: Education and Society'] (Paris: l'Harmattan, 1996), 85.

25. Borhane Erraïs, 'Discours sportif à vocation méditerranéenne: L’exemple tunisien, 1956-1985' ['The Discourse of Sport around the Mediterranean: The Case of Tunisia'], in 'Confluences Méditerranée: Sport et politique, JO D’Athènes. Jeux Méditerranéens. Géopolitiques, nationalisme et "business"', Femmes, Islam et islamisme, no. 50 (2004), 59.

26. Erraïs, Archéologie d'un discours politique, sport et construction nationale ['Archeology of a Political Discourse and Nation Building'].

27. At the beginning of the 1960 s, $55 \%$ of Tunisians were below the age of 20 . This fact could have become a threat if nothing had been done to channel these young people's energies. Borhane Erraïs and Mohamed Ben Larbi, 'Itinéraire d'une pratique: l'escrime en Tunisie' ['A Sporting Itinerary: Fencing in Tunisia'], Cahiers de la Méditerranée 32, no. 1 (1986), 39-47.

28. According to Edgar Morin, 'the state is the historical-sociological nucleus of the nation'. Edgar Morin, 'Pour une théorie de la nation' ['For a theory of the nation'], cited in Erraïs, Archéologie d'un discours politique, sport et construction nationale ['Archeology of a Political Discourse and Nation Building'], 154. In a book entitled Le sport \& les sports autrement, published in 2016, Béchir Jabbes, a former general commissioner for sport (1991-1993), on page 148 defined the state as 'a socio-political entity which controls and supervises all the cogs of the country ... it has sole responsibility for facilitating access to sport for every citizen ... it is the state that defines the model of development'.

29. Erraïs, Archéologie d'un discours politique, sport et construction nationale ['Archeology of a Political Discourse and Nation Building'], 154.

30. Bourguiba referred to sport in several speeches between 1960 and 1961, with comments including 'We must view sport as a vital issue for which the state has a responsibility towards the people'; 'Without sport, young people's education would be incomplete. It allows people to expand their capabilities and sharpens their minds. It is a significant element in their culture. Increasing mankind's abilities requires efforts in every field and this is the price by which a person becomes a useful citizen, capable of controlling their emotions, healthy in mind and body, and endowed with high morals. That person is civilized and more conscious of belonging to a highly evolved people'; 'the effort I am asking you to make is part of the huge war we are waging on underdevelopment ... Because everything contributes to underdevelopment: intellectual backwardness, physical decline, degeneration of moral values. We must bring this to the people's attention. They need to be aware of this ...; 'My primary objective is to ensure the Tunisian people understands the importance our young nation attaches to sport and the efforts we expect them to make in order to improve our country in every domain'. Habib Bourguiba, 'Le role du sport dans la bataille contre le sous-développement', Discours, tome VIII, 1960-1961 (30 September 1960), cited in Erraïs, Archéologie d'un discours politique, sport et construction nationale ['Archeology of a Political Discourse and Nation Building'], passim. 
31. Number of medals won by Tunisia’s women athletes at the Mediterranean Games: Beirut 1959 (Lebanon) - six; Naples 1963 (Italy) - two; Tunis 1967 (Tunisia) - 25; Izmir 1971 (Turkey) - 11; Alger 1975 (Algeria) - seven; Split 1979 (Yugoslavia) - 12; Casablanca 1983 (Morocco) - nine; Latakia 1987 (Syria) - 11.

32. Erraïs, Archéologie d'un discours politique ['Archeology of a Political Discourse and Nation Building'].

33. Habib Bourguiba, 'Le role du sport dans la bataille contre le sous-développement', Discours, tome VIII, 1960-1961 (30 September 1960), cited in Erraïs, Archéologie d’un discours politique, sport et construction nationale ['Archeology of a Political Discourse and Nation Building'], 244.

34. This state intervention was made official through the Act of 9 February 1960, on regulating civilian sport. It gave the Secretary of State control over the running of sports federations and associations and made them responsible for all aspects of the quantitative and qualitative development of sport.

35. Under Article 2 of Decree no. 77-552 of 20 June 1977, on the creation of Sports Coaching Departments, Technical Directors were sports ministry officials who were seconded to a sport federation. As a result, they were also ensured a seat on their federation's executive board.

36. Erraïs, Archéologie d'un discours politique sport et construction nationale ['Archeology of a Political Discourse and Nation Building'].

37. As well as being a world-class sprinter, Bouabdallah Beya played basketball, handball, and volleyball. She represented her country in three of these sports: athletics, basketball, and handball.

38. A gold medal in the shot put and a silver medal in the javelin. Tunisia's women won two more medals at the 1967 Mediterranean Games thanks to Djemai El ham (silver in the shot put) and Jamila Ben Badr (gold in the javelin).

39. Until then, the CNOT had been presided over by Ben Abdelkader, who had been elected legitimately by the sport movement in recognition of his long career championing sport.

40. Erraïs, 'Discours sportif à vocation méditerranéenne' ['The Discourse of Sport around the Mediterranean'].

41. Under Articles 1 and 2 of Decree No. 59-143 of 8 May 1959, a National Olympic Day is held every year on the third Sunday in May. In addition, the CNOT is allowed to use this occasion to collect funds from the public to support Tunisia's participation in Olympic and regional games.

42. Erraïs, Archéologie d'un discours politique, sport et construction nationale ['Archeology of a Political Discourse and Nation Building'].

43. Taoufik Haouet, 'Le Sport tunisien face au développement: une approche systématique suivie d'une analyse dialectique' (PhD diss., Université Paris 7, 1981).

44. Source: World Bank national accounts data, http://data.worldbank.org/indicator/NY.GDP. PCAP.CD.

45. Chouikha and Gobe, Histoire de la Tunisie depuis l'indépendance ['History of Tunisia since Independence'].

46. Mohamed Mzali (1925-2010) was a Tunisian politician who ran several different ministries between 1969 and 1980 before he took over from Hédi Nouira as head of the government in 1980 (Picollec, Outre-Mers T. 97, no. 364-5, 2009). In his book Un premier ministre de Bourguiba témoigne, Mzali wrote 'My sentimental attachment to the man who was like a second father to me prevented me from realizing how heavy a burden I was taking up'. Mzali (2004), 34, cited in Maria Romo-Navarrete, 'Mzali Mohamed: Un Premier ministre de Bourguiba témoigne' ['Mzali Mohamed: Memoirs of a Prime Minister under Bourguiba'], in Outre-Mers 96, no. 364-5 (2e semestre 2009), 'Le Sport dans l'Empire Français. Un instrument de domination coloniale?' ['Sport in the French Empire. An instrument of Colonial Domination?'], 383.

47. Among other measures, he banned physical education teachers from also accepting positions as coaches.

48. The team's first Olympic qualification was for the 1960 Olympics in Rome.

49. An uprising known as the 'Bread War' led to an unstoppable wave of riots across the country that left 70 people dead and 550 injured. Bourguiba had to cancel the decision to increase the price of bread in order to bring the riots to an end and save the government. Erraïs, Archéologie d'un discours politique, sport et construction nationale, L'exemple tunisien ['Archeology of a Political Discourse and Nation Building'] (Doctoral thesis, Université de Paris VII, Jussieu, 1992). 
50. Driss Abbassi, Entre Bourguiba et Hannibal: Identité tunisienne et histoire depuis l'indépendance ['Between Bouguiba and Hannibal: Tunisia's Identity and History since Independence'] (Paris: IREMAM-Karthala, 2005).

51. This family circle comprises several different clans: the Ben Alis, the Trabelsis (the brothers and nephews of Ben Ali's second wife) and the wheeler-dealers Slim Chiboub (Dorsaf Ben Ali's husband), Marouan Mabrouk (Cyrine Ben Ali's husband), Slim Zarrouk (Ghazoua Ben Ali's husband) and Sakhr El Matri (husband of Nesrine Ben Ali, Ben Ali's first daughter with Leila Trabelsi). Chouikha and Gobe, Histoire de la Tunisie depuis l'indépendance ['History of Tunisia since Independence'].

52. Chouikha and Gobe, Histoire de la Tunisie depuis l'indépendance ['History of Tunisia since Independence'], 57. For Putnam and Graziano, 'clientilism is a breakdown in democracy and a misappropriation of government institutions brought on by political leaders whose sole concern is remaining in power'. See Robert D. Putnam, Making Democracy Work: Civic Traditions in Modern Italy (Princeton, NJ: Princeton University Press, 1993); and Luigi Graziano, Clientelismo e sistema politico (Turin: Franco Angeli, 1984), cited in Nadim Nassif, 'Analyse de la politique du sport au Liban, 1991-2012' ['Analysis of Sport Policy in Lebanon, 1991-2012'] (PhD diss., Grenoble, dans le cadre de École doctorale ingénierie pour la santé, la cognition, l'environnement (Grenoble), in partnership with Laboratoire Sport et Environnement Social (équipe de recherche), 2013).

53. A. Drissi, 'Sport et usages politiques du passé dans la Tunisie des débuts du XXIe siècle', Politique et Sociétés 26, no. 2-3 (2007), 125-42.

54. Source: World Bank national accounts data, http://data.worldbank.org/indicator/NY.GDP. PCAP.CD.

55. They took part in nine events in athletics ( 100 metres sprint, 80 metres hurdles, long jump, high jump, shot put, and javelin) and swimming (100 metres freestyle, 100 metres backstroke, and 100 metres breaststroke).

56. As reflected in an interview given by Neziha Zarrouk, Minister for Women's Affairs and the Family, at the 2001 Mediterranean Games: 'The results achieved in several disciplines show how far Tunisian women have come and the position they have in the strategic framework drawn up by President Zine el Abidine Ben Ali. La Presse de Tunisie, 14 September 2001, 3, cited in Drissi (2007).

57. For example, French politician Philippe Séguin declared: 'Tunisia, a young dragon, could not be satisfied with just economic and social success; she wanted, quite rightly, to reap the rewards of her great investment in sport and youth by becoming Africa's football champions', La Presse de Tunisie, 15 February 2004, 9, cited in Drissi (2007). Similarly, Josef Blatter expressed 'his profound gratitude to President Ben Ali for the great efforts he has unceasingly made in order to ensure the success of the 2004 Africa Cup of Nations', La Presse de Tunisie, 23 January 2004, 9, cited in Drissi (2007).

58. 'In fact, as of 2001, the president's party, the Constitutional Democratic Assembly, launched a propaganda campaign, which was widely broadcast by the national press, to call upon the head of state to stand in the 2004 presidential election'. Khaled ben M'barek, 'Chronique politique Tunsie', Annuaire de l'Afrique du Nord, XXXIX 2000-2001 (2003), 401-34; Vincent Geisser and Eric Gobe, 'Chronique politique Tunisie', Annuaire de l'Afrique du Nord, XLI 2003 (2005), 291-320. Cited in Abbassi, 'Sport et usages politiques du passé dans la Tunisie des débuts du XXIe siècle' ['Sport and Past Political Practices in Early 21st-Century Tunisia'], 129.

59. Abbassi, 'Sport et usages politiques du passé dans la Tunisie des débuts du XXIe siècle' ['Sport and Past Political Practices in Early 21st-Century Tunisia'], 130.

60. S. Khiari, 'Mondialisation et démocratie: Le contre-exemple Tunisien' ['Globalization and Democracy: The Tunisian Exception'], Confluences Méditerranée 4, no. 51 (2004), 91-101.

61. Chouikha and Gobe, Histoire de la Tunisie depuis l'indépendance ['History of Tunisia since Independence'], 59.

62. 'The street, schools, neighborhoods, businesses, health services, sport and other leisure activities. The police are, of course, omnipresent, and the RCD and its countless tentacles, neighborhood committees, sports and cultural clubs, and thousands of professional, regional, 
specialist and charitable associations form a tight grid designed to monitor, repress, ensure the dependence and corrupt a large part of the population. Today, there are no links/relations that are not subject, in one way or another, to state control or to one of the official or unofficial bodies of the Interior Ministry, which frequently merge with ordinary administrative mechanisms'. Khiari, 'Mondialisation et démocratie' ['Globalization and Democracy'].

63. During the Ben Ali period, Tunisia's only political party was the Democratic Constitutional Rally (RCD), formed in 1988 with Ben Ali at its head, which claimed to be open to all good people. Chouikha and Gobe, Histoire de la Tunisie depuis l'indépendance ['History of Tunisia since Independence'].

64. B. Jabbès, Sport et revolution: C'est pour quand? Les pages noires du sport tunisien (2001).

65. Founded in 1991, Espérance Sportive de Tunis (EST), originally known as 'Espérance Sportive,' was Tunisia's first sports club. In colonial times, sports events were used to transmit nationalist messages. Erraïs, Archéologie d'un discours politique, sport et construction nationale ['Archeology of a Political Discourse and Nation Building']. In fact, 'matches between Tunisian (Espérance Sportive) and French (Stade Gaulois) clubs were veritable political clashes'. Erraïs and Larbi, Itinéraire d'une pratique ['A Sporting Itinerary'], 44.

66. François Alaphilippe, 'Le pouvoir federal: Pouvoirs', Revue française d'études constitutionnelles et politiques, no. 61 (1992), 71-84.

67. Finance Act (no. 79-66), 31 December 1979.

68. Jabbès, Sport et revolution.

69. Jean-Paul Callède, 'Les politiques du sport et leurs metamorphoses' ['Sport Policies and their Metamorphoses'], Informations sociales, no. 187 (2015), 14-23.

70. Ibid.

71. Jabbès, Sport et revolution.

72. Article 14 (new) - 'A sport federation will be run by a federal bureau consisting of members directly elected by the general assembly. Its statute and internal regulations will lay down specific procedures for elections to the federal bureau, covering conditions for candidates, the election procedure and all aspects of vote counting and the announcement of results'.

73. Judo, taekwondo, wrestling, athletics, sport for all, karate, dance-sport, kyokushinkai and martial arts, chess, and boxing.

74. Since the revolution, the MJS has been headed by five different ministers and the ministry has changed its name three times: Ministry of Youth and Sports, Ministry of Youth, Sports, Women and the Family, Ministry of Youth and Sports Affairs. Source: Ministry of Youth and Sports website: http://mjs.tn/fr.

75. Henry, 'European Models of Sport'.

76. S. Montchaud and P. Dantin, Le modèle sportiffrançais, bilan et perspectives (Lavoisier: Hermès Science Publications, 2011), 344.

77. Henry, 'European Models of Sport', 134.

\section{Disclosure Statement}

No potential conflict of interest was reported by the authors.

\section{Notes on Contributors}

Maha Zaoui is a university assistant in sports management at Institute Superior of Sport and Physical Education, Kef, Tunisia. She specializes in the management of sports federations and is working on intragroup conflict in sport federation and its impact on performance in Tunisia.

Emmanuel Bayle is currently professor in sports management at the Institute of Sport Sciences of the University of Lausanne (ISSUL). He has published several books and articles on sports management (global sport leaders, governance in sport organizations, CSR and sport, professional sport clubs and CSR) and also on CSR, and on non profit management. 